\title{
Travelling The Famished Road of Ben Okri or How to Revolutionize the World by Revolving Inward
}

\section{Fanny Monnier}

\section{(2) OpenEdition}

1 Journals

Electronic version

URL: https://journals.openedition.org/ces/698

DOI: $10.4000 /$ ces. 698

ISSN: 2534-6695

Publisher

SEPC (Société d'études des pays du Commonwealth)

\section{Electronic reference}

Fanny Monnier, "Travelling The Famished Road of Ben Okri or How to Revolutionize the World by Revolving Inward", Commonwealth Essays and Studies [Online], 42.1 | 2019, Online since 20 December 2019, connection on 22 September 2021. URL: http://journals.openedition.org/ces/698 ; DOI: https:// doi.org/10.4000/ces.698

This text was automatically generated on 22 September 2021.

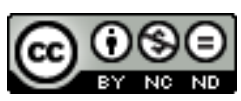

Commonwealth Essays and Studies is licensed under a Licence Creative Commons Attribution - Pas d'Utilisation Commerciale - Pas de Modification 4.0 International. 


\title{
Travelling The Famished Road of Ben Okri or How to Revolutionize the World by Revolving Inward
}

\author{
Fanny Monnier
}

1 The term revolution may imply a sudden change, a violent political upheaval that gives birth to a new form of government. Alternately, it may refer to "a very important change in the way that people do things," which in some cases is linked to the notion of revolving, that is the completion of "a circular movement" (Cambridge Dictionary, online). This dual meaning is exemplified in The Famished Road by the narrator, Azaro, who lives in Nigeria at the time when the country was moving towards independence. In the first pages of the novel, Azaro, a spirit child, chooses to remain in the world of the living, thus forsaking the spirit world. With his decision to stay, he puts an end to the endless, circular return of the abiku who keeps being born into the world of the living before going back to the spirit world. At the same time, in acting this way, Azaro does something that no other spirit child would dream of doing. By putting an end to the endless cyclical revolution of reincarnation, Azaro performs a truly revolutionary and ground-breaking act. At the beginning of the novel, his controversial decision to remain with his birth parents has already brought radical change and there is great potential for more transformations, notably in the political situation of the country. Transformation may occur in two different spaces: in the outside world with political independence, and within the self with the evolution of the characters - to which one should add transformation in the reader's perspective. This essay examines these various forms of "revolution" in The Famished Road. When analysing the diegesis, revolution as change hardly seems to apply to The Famished Road as changes are not to be found. Instead, what the novel offers is repetition or even indirection. Thus, the idea of revolution as circular movement seems to take precedence, unless the reader focuses on inner transformation, that is a transformation of the self through a revolution in perception. 
2 As the action of the novel takes place a little before independence, one expects drastic changes to unfold. Yet, although at first sight, potential change is present, it later becomes clear that revolution in the sense of a sudden transformation in the country is not to happen. The upcoming shift in politics foreshadows transitions in society with the political elections and the independence of the country. As Azaro's mother declares, "[t] $]$ is is a new age. Independence is coming" (Okri 1991, 109), showing the dramatic impact of such an event on the lives of Azaro and his family. Dad also hints at this when he tells his son that "new things [are] happening in the world and in our area" (490). Azaro himself makes references to change throughout the novel, implying that transformation is occurring. As elections are on the way, the only two existing political parties, the Party of the Rich and the Party of the Poor, travel around the country to let everyone know about their programs, which are supposed to bring change. The first party to come to the compound where Azaro and his parents live is the Party of the Rich. They promise many things:

WE WILL FEED YOUR CHILDREN [...] AND WE WILL BRING YOU GOOD ROADS [...] AND WE WILL BRING ELECTRICITY [...] AND WE WILL BUILD SCHOOLS [...] AND HOSPITALS. WE WILL MAKE YOU RICH LIKE US. THERE IS PLENTY FOR EVERYBODY.

PLENTY OF FOOD. PLENTY OF POWER. VOTE FOR UNITY AND POWER. (145)

The repetitive use of the modal WILL shows a projection into the future. Interestingly, with the pronoun "we" as subject, the modal SHALL would have been expected. This, however, would have implied that the politicians were making a promise they know they will not be able to keep. Furthermore, if WILL often contains an idea of resolution, this feeling is not really present here. In comparison, the use of BE GOING TO would underline a clear intention. Steps would already have been taken towards a potential action that would happen soon. However, the Party cannot promise imminent transformations. WILL can be stressed to express a determination to make sure that the action is realised. The problem is that in the extract, every word is stressed with the use of capital letters, thus downplaying that possibility. As a consequence, what we get in this passage is a simple declaration of intention without any real plan for action. The politicians only state what they want to achieve but they cannot say whether their policy will bear fruit. This lessens the impact of the speech and the numerous repetitions of WILL further empty the modal of its potential meaning. WILL becomes an empty shell that we do not pay attention to anymore and the speech becomes a declaration of empty promises. Indeed, the party offers powdered milk to the hungry population, a milk that later proves to be rotten, making everybody in the compound sick. The Party of the Poor is no better, making vague promises: "They too had come with loudhailers and leaflets and had promised a lot of things" (177, emphasis added).

Other potential sources for revolution are the riots led by the population at several moments in the book. At the very beginning of the novel, the reader nearly gets the feeling of a revolution occurring as the compound goes up in flames. The landlord who is certain that the inhabitants are responsible for the fire calls the police, who, for no reason, start flogging people, leading to riots. At that moment, people react to police brutality and to colonial rule as they "[tear] their colonial uniforms and [send] them packing" (12). Similarly, later in the novel, the Party of the Rich returns to the compound after the rotten milk episode. People are ready to act and attack the politicians, the thugs that came with them, and the van in which they arrived. Contrary to the situation in the first riot, the police are now helpless. Moreover, thanks to the photographer, Jeremiah, the news appears in a national newspaper: 
For the first time in our lives we as a people had appeared in the newspapers. We were heroes in our own drama, heroes of our own protest. There were pictures of us, men and women and children, standing helplessly round heaps of the politicians' milk. There were pictures of us raging, attacking the van, rioting against the cheap methods of politicians, humiliating the thugs of politics, burning their lies. The photographer's pictures had been given great prominence on the pages of the newspaper and it was even possible to recognise our squashed and povertyridden faces on the grainy newsprint. There were news stories about the bad milk and an editorial about our rage. We were astonished that something we did with such absence of planning, something that we had done in such a small corner of the great globe, could gain such prominence. (184)

For once, the poverty-ridden people, who have nothing, are in possession of their "own" fate and they act on it as conveyed by the numerous action verbs. The use of the pronouns "we" and "us" shows the unity of the compound people. The plural "we" becomes singular as the people become "a people" in the expression "we as a people."

If change can affect a whole population, it can also occur on a more personal level. Madame Koto, the owner of a bar, goes through a major physical transformation as she becomes pregnant and keeps getting bigger, leading to pain in her foot. Her transformation is concomitant with the changes in her bar, which expands continuously. Dad also keeps evolving. In the course of the book, he becomes a boxer, he begins to take an interest in politics and seeks to bring change to the compound by turning into a politician.

5 However, despite a certain potential for revolution, what eventually prevails in the novel is a lack of real change. First, some changes are forgotten because they have not been recorded. For instance, a second riot that occurs against the Party of the Rich is forgotten because the photographer has not taken any photos of the event:

And because the photographer hadn't been there to record what had happened that night, nothing of the events appeared in the newspapers. It was as if the events were never real. They assumed the status of rumour. [...] After a while, when nothing happened, when no reprisals fell on us, it seemed that nothing significant had happened. Some of us began to distrust our memories. We began to think that we had collectively dreamt up the fevers of that night. (214)

Here, the repetition of "nothing" further cancels the existence of the event. If some changes are forgotten, others simply fail to come to pass.

Upon closer examination, the promised political transformations and independence never occur, be it in The Famished Road or in the rest of the trilogy. The only event worth noting is "the endlessly postponed [political] rally" (180), which eventually takes place in Infinite Riches, the last volume of the trilogy. It is followed by riots which, like all the others, have no consequences other than violence. During the first riot, people act blindly. They simply react to the violence shown by the police and copy gangs that seek only to destroy: "gangs materialised in the darkness. They stamped through the mud. At the main road, they fell on cars and buses. They attacked police vehicles. They looted shops. Then everyone began looting, burning, and overturning things" (12). We can notice that there is a single reference to the police, enclosed with references to other vehicles and shops belonging to people that are in no way responsible for what happened. In the end, the succession of the three verbs introducing the noun "things" underlines that people's anger at the police has turned to meaningless destruction aimed at "things." In the case of the second riot, the rage of the people is qualified as "impotent" (182). The people have anger but no power to change the situation. Furthermore, afterwards, Dad confides in Azaro: “Trouble always happens after 
celebration. Trouble is coming to our area" (186), suggesting that the only consequence of the riot is going to be reprisal. This absence of change is further underlined by Azaro, who keeps remarking that "Nothing unusual happened" (208), or that "nothing ever happened in the world" (309). This counteracts the quotes noted earlier suggesting potential transformations, and this continues right through until the very end of the novel as Azaro notes on the last page: "Nothing happened" (574).

7 Finally, going back to the characters' evolution, Madame Koto's pregnancy is neverending, and she actually dies before having the chance to give birth, thus drawing a parallel between the impossible birth of her triplets and the forever delayed birth of the nation. As for Dad, his projects are repeatedly thwarted. He fails to convince people as a politician and when he decides to put the beggars living near the compound to work at clearing the refuse from the streets, it is a complete disaster. Consequently, the general impression produced by the novel is that, as Azaro notes, nothing changes. Rather, the story seems to be going in circles through repetitions, performing another sort of revolution.

8 If nothing really happens in the novel, leading to an overall impression of randomness as if the story were going nowhere, another form of revolution is however very much present: repetition, as the novel seems to be revolving onto itself. Brenda Cooper noted that in The Famished Road, "[n]ot much happens. What does transpire seems familiar and repetitive" $(1998,68)$. To the reader, it often feels as if nothing were happening. As Azaro remarks, "Time did not move at all" (Okri 1991, 309) and the text seems to lack a sense of direction. The conventional movement of the novel, from beginning to end, is called into question with a starting point that underlines the existence of a before with Azaro's previous lives as an abiku, and an ending which offers no conclusion but instead, an opening with the concluding statement: "and then it was another morning" (574). This aspect has been underlined by Kerry-Jane Wallart: "Notions of order, sequence and series but also the very idea of a beginning or an end thus seem threatened or seriously revisited [...]. Ben Okri constantly suggests that some meaning will be revealed, even as he postpones such revelation" $(2013,31)$. Expectations are constantly thwarted. For Christopher Ringrose, "the experience of reading The Famished Road is to set out on aborted journeys, to be moved and then have that emotion left in suspension as the book takes another turn" $(2013,42)$. Mum and Dad tell Azaro stories which the reader never hears, or which have no ending. In Songs of Enchantment, the second book in the trilogy, Mum herself remarks to Dad: "Your story isn't going anywhere" (Okri 1993, 267). When Azaro travels with a three-headed spirit, he discovers a people that continuously build a road to heaven that will never be finished as it keeps being destroyed. Thus, incompleteness leads to indirection and the people move in circles as they keep building the road over and over again.

Similarly, the diegesis contains many instances of repetitions and it often feels as if the story were going round in circles instead of moving forward. Several critics have pointed to this. Renato Oliva explains that repetitions "[produce] an effect of cyclical recurrence and immutability, and [suggest] the Eternal return of the identical" (1999, 188). For Vanessa Guignery, "what prevails in the novel is a sense of fluidity, repetitiveness, circularity and seeming randomness" $(2012,63)$. Wallart notices this as well:

Madame Koto, the photographer, walks in the forest, frantic dances in the bar, strifes [sic] with the spirits, domestic scenes at dusk, all of these have a notorious 
tendency to come back irrepressibly, while the situation of Azaro undergoes no drastic evolution in the course of this long novel. $(2013,32)$

Besides the repetition of scenes, the modal "would" is often used in its iterative form to underline the repetitiveness of certain actions. What is more, the novel is filled with the idea of the cycle with references to "a cycle coming to an end" (Okri 1991, 570) for instance. This starts at the very beginning of the book with the image of the abiku, and later on, of the abiku nation that keeps being reborn. This notion of rebirth is further explored with Azaro dying and coming back to life and Dad nearly dying and then wondering: "How many times is a man reborn in one life?" (414). However, if the trilogy appears to offer "circular stories" (Okri 1998, 120), upon further examination, it becomes clear that these apparent repetitions are never exactly the same. Instead of a circle, what we get is a spiral.

As Wallart explains in her article, between the absence of a forward movement, or of real change, and a circular motion, what is actually present in the novel is a spiral: "The evolution of the narration thus comes to depend on a spiral that foregrounds a movement combining the circle and the line" $(2013,30)$. This idea of the spiral as being similar but never exactly the same is central to Ben Okri's works. The spiralling movement appears to go back to the origin but never fully does. There is always a small change, a slight twist. This point has been addressed by Okri himself:

In terms of The Famished Road I've been accused by certain ruler-headed readers of repetition. I often wanted to sit them down with a nice glass of wine and say: "what you see as repetition is not really repetition. It's a spiral." It appears to go back to the same place but it doesn't. There's a constant micro transformation in perception at every point of that spiral. (Guignery and Pesso-Miquel 2013, 26)

Christopher Ringrose described this aspect of the novel as "turbulence and surprisewithin-familiarity" $(2013,41)$. Events that seem repetitive keep coming back with small alterations and Ringrose underlines the fact that "Okri is endlessly inventive in restaging these journeys, this to-and-fro movement, exhausting the reader and yet giving some sense of development" (41). One example is the apparent repetition and build-up of the phrase "riddles that only the dead can answer" throughout the novel. Early on, Dad asks "riddles that only the dead can answer" (Okri 1991, 39). He soon tells his son that "life is full of riddles that only the dead can answer" (48). Later, the expression is used again by Azaro who ponders over "a riddle that not even the dead can answer" (267) and states that "there are many riddles of the dead that only the living can answer" (489). The last occurrence is introduced by Azaro who further notices that "there are many riddles amongst us that neither the living nor the dead can answer" (559). Each time it is used, the phrase becomes longer and more complex. It expands, like a spiral, throughout the text as the characters, Dad and then Azaro, learn more and further understand this "riddle": the separation between the living and the dead, suggested by the first statements, appears to dissolve in the face of the mysteries of the world. Another example of the spiralling structure of the novel can be found in the fights Dad has with his various opponents. Although similar, the fights are always slightly different. If Dad is battered every time, his opponents (Yellow Jaguar, Green Leopard, the man in the white suit) vary and become more and more challenging as Dad himself gains in strength.

11 Beyond actions, the spiralling structure can also be found in the treatment of time and this has much to do with the fact that the narrator is a spirit-child. At the beginning of the novel, Azaro recognizes: "I had no idea whether these images belonged to this life, 
or to a previous one, or to one that was yet to come" (8). For him past, present and future are one and the same. As Adnan Mahmutović writes: "We find a kind of ecstatic model of spiral time in which the present, the past, and even the future stretch into one another" $(2013,146)$. Likewise, for Wallart:

It is the spiral of life as seen from the point of view of the abiku, who dies and is reborn without there being any interruption nor straight continuity. The abiku [...] is not a reiteration but the exploration of a new direction, in a whirl, a succession of circling loops. $(2013,40)$

The abiku offers another way of perceiving reality as it is connected to the spirit world. Nonetheless, the abiku combines two conflicting aspects regarding the notion of revolution. On the one hand, as Wallart points out, he offers a new direction to the reader. On the other hand, with the exception of Azaro, abikus experience cyclical movements of life and death, indefinitely. In an interview with Jane Wilkinson, Okri suggested that maybe "we are all abikus" (Wilkinson 1992, 84). This would imply that as an abiku, the reader can move in a new direction but is also at risk of going in circles. The goal then, would be to become more like Azaro, in other words to break the cycle of iteration and to reconnect to life in order to change one's perceptions. With The Famished Road, Okri does not merely seek to entertain but also, if not mostly, to introduce his reader to a new way of seeing, of perceiving and of thinking. In order to create this revolution in perception, the writer offers a reading experience that lets the reader go inward in a process akin to meditation in order to change, and potentially change the world later on.

If The Famished Road deals with the upcoming changes to be expected as an unnamed African country becomes independent, Ben Okri does not want to reduce his work to its colonial or post-colonial aspects. On the contrary, he endeavours to change minds, as he explains in an interview with Pietro Deandra: "I am interested in affecting consciousness. I do not have time for idle exercises on colonisers and so on. It seems to me defeatist. I am much more interested in transforming consciousness, which goes beyond colonialism" (Deandra 1994, 66). As Sarah Fulford states, for Okri: "the role of the artist is [...] to diffuse [the] disengagement between the earthly and the spiritual to create a conduit between the material world and the ideal world" $(2009,244)$. The artist should seek to open minds and to help people reconnect to the spiritual.

According to Okri, in order not to move round in circles in life, one has to learn from one's experiences. If an event is not experienced fully or not remembered, then it can come back. For instance, after a riot against the Party of the Rich, the people from the compound start doubting whether the riot happened because, contrary to the previous one, no photos were taken by Jeremiah to record the event. As a consequence, "the wind of recurrence [blows] gently over the earth" (Okri 1991, 215). This principle is further explored in Astonishing the Gods. In this other novel by Okri, the main character visits a city, the first law of which is that "every experience is repeated or suffered till you experience it properly and fully the first time" $(1995,46)$. Not only is it by experiencing life fully that we can move forward and bring change to the world, but unless we change the way we perceive the world, nothing can change. How, then, does Okri plan to revolutionize the reader's perceptions?

Elizabeth Syrkin rightfully argues that "The Famished Road elaborates a trans-realist perception and approach to writing that can, in Okri's words, 'restore the kingdom' of the mind to the dimensions hidden within it" (2013, 54-55). Through a trans-realist aesthetic, Okri complexifies our notion of the real and opens our minds to all its porous 
and hidden layers. However, if trans-realism can help change consciousness, I would argue that Okri may also have had in mind meditation, which in itself is another form of revolution, to further manifest changes in his readers. In the fifteenth century the verb "revolve" - from the Latin "revolvere" which later produced the noun "revolution" - referred to the idea of turning over, or meditating (Online Etymology Dictionary). This meaning still exists today as "revolving" can mean "to turn over" or "to reflect" (Webster's Revised Unabridged Dictionary, online). When Azaro "[sits] outside watching the world revolve slowly with the movement of clouds" (Okri 1991, 490), the revolution of the world gives way to another revolving movement as Azaro starts meditating, being mindful of the movement of the clouds in the sky.

Meditation often implies a focus on the body, notably with a practice known as bodyscan, in which the person focuses on the different parts of his/her body in order to connect to it. This practice, in the same way as a focus on breathing, helps calm the mind and its thoughts. As such, connecting to the body helps one connect to the mind. In a previous article: "Lire The Famished Road, Expérience du Corps," I showed how the novel creates an empathic reading experience by affecting the reader physically. I suggested that the purpose of this experience was to reach a more spiritual level (Monnier 2018, 49). Here, I would like to further develop that idea and suggest that reading The Famished Road is at times akin to meditating. First and foremost, through the empathic reading experience, Okri forces the reader to reconnect to his/her body. This experience can be linked to the practice of vipassana meditation which focuses on self-observation notably through a focus on the physical self. Secondly, transcendental meditation advocates the repetition of a mantra as, by repeating it, the person will pay less and less attention to its meaning. That way, practitioners can loosen their grip on their thoughts and let go to the point of reaching a certain level of relaxation and deeper mental focus. As I showed previously, repetitions are central in the novel and as events and sentences keep being repeated throughout the text, the reader may let go of his/her mental barriers regarding the novel and begin to accept a new perception of reality. One final form of meditation that is central in the book is that of mindfulness. This form mainly occurs as the reader follows a character who, as a spirit-child, not only sees the world differently but also sees more than the others. As a child and as an abiku, Azaro sees the world anew and through him, the reader does as well. Thus, at times, reading the novel may feel like going through a meditation practice with the text seeking to guide readers towards a process of contemplation.

We may wonder about the purpose and the effects of such reading as meditation. As I hinted earlier, "meditation is primarily concerned with caring for the mind" (Lama Zopa Rinpoche 2019). In fact, research suggests that meditation affects the structure of the brain. If further studies still need to be undertaken, "there is emerging evidence that mindfulness meditation might cause neuroplastic changes in the structure and function of brain regions involved in regulation of attention, emotion and selfawareness" (Tang, Hölzel and Posner 2015, 10). For Rebecca Gladding, with meditation practice, "you are able to see yourself and everyone around you from a clearer perspective, while simultaneously being more present, compassionate and empathic with people no matter their situation" (2019), that is whether they are like or unlike you. For the readers of The Famished Road, this could mean being more understanding of people from a different cultural background. Beyond the neuronal aspect and on a more spiritual level, meditation is said to help move away from endless repetitions in life, or even from repetitive reincarnations. As an abiku, Azaro has experienced these 
endless and repetitive cycles of lives. Similarly, if we are to believe Okri's idea that "we are all abikus" (Wilkinson 1992, 84), we could all experience this coming and going. According to Lama Zopa Rinpoche, mindfulness is essential for experiences to be lived fully. Consequently, being mindful can help one to avoid having to go repeatedly through certain events as it can help truly connect to each experience. Finally, for Lama Zopa Rinpoche the purpose of meditation is enlightenment for oneself and for others. This question of enlightenment is thoroughly developed in Songs of Enchantment as Okri introduces readers to "The African Way": "The Way that keeps the mind open to the existences beyond our earthly sphere, that keeps the spirit pure and primed to all the rich possibilities of living, that makes of their minds gateways through which all the thought-forms of primal creation can wander and flower" (1993, 160). Enlightenment is also central to The Famished Road. Dad learns to see, that is to be mindful. In doing so, he better understands the world around him and in a way, we could argue that he becomes more enlightened. In other words, what potentially occurs through reading the novel is a spiritual revolution through a spiralling movement leading the reader back to the center.

Earlier on, I analysed the spiralling structure of the novel, explaining that subtle changes occur in the text, leading the spiral to become larger and encompass more. Conversely, what happens with the revolution of the mind is an inward movement, that is a reversal of the spiral as the reader goes deeper within himself or herself, to the center or the beginning of the spiral to induce a spiritual revolution. This notion of beginning leads us to the image of the road and the river which is central in the novel. From the very first page of the book, the reader is told: "In the beginning there was a river. The river became a road and the road branched out to the whole world. And because the road was once a river it was always hungry" (Okri 1991, 3). If the river has turned into a road, at times it can revert back to its original state, notably in the case of floods. Although linked in the novel, the road and the river have different connotations. The road is envisioned as a rather negative force but considering it as "evil" would be an "oversimplification" for Gillian Gane who underlines the manifold possibilities and significance of the roads in the novel $(2007,50)$. Besides eating people, the road can lead anywhere, meaning characters can get lost because of the multiple tracks:

The road seemed to me then to have a cruel and infinite imagination. All the roads multiplied, reproducing themselves, subdividing themselves, turning in on themselves, like snakes, tails in their mouths, twisting into labyrinths. The road was the worst hallucination of them all, leading towards home and then away from it, without end, with too many signs, and no directions. The road became my torment, my aimless pilgrimage, and I found myself merely walking to discover where all the roads lead to, where they end. (Okri 1991, 134-35)

Fully alive, the road imposes its will onto Azaro. Like a giant snake, with its tail in its mouth, it seems to multiply endlessly while simultaneously always leading back to the same point as "where all the roads lead to" is "where they end" - that is, the road leads nowhere. In contrast to this beastlike road, while travelling with a three-headed spirit, Azaro discovers an endless, magnificent road to heaven that is forever under construction:

I looked at the road with new eyes. It was short and marvellous. It was a work of art, a shrine almost, beautiful beyond description, created out of the most precious substances in the world, out of amethysts and chrysoberyl, inlaid with carnelian, brilliant with patterned turquoise. 
'Why is it so beautiful?'

'Because each generation begins with nothing and with everything. They know all the earlier mistakes. They may not know that they know, but they do. They know the early plans, the original intentions, the earliest dreams. Each generation has to reconnect the origins for themselves. They tend to become a little wiser, but don't go very far. It is possible that they now travel slower, and will make bigger, better mistakes. That is how they are as a people. They have an infinity of hope and an eternity of struggles. Nothing can destroy them except themselves and they will never finish the road that is their soul and they do not know it.' (379)

What the three-headed spirit hints at here is that it is necessary to reconnect to the origin to truly grow and that this growth is endless. The road itself is "hungry for great transformation" (211). The problem of the road in the novel is that it also represents all the various possibilities of life, which are manifold. Consequently, one can get lost or go in circles. As the king of spirits tells Azaro: "you have to travel many roads before you find the river of your destiny" (6). If the river represents both the origin and the path to destiny, this could imply that it is necessary to go back to the river, to travel back to the center of the spiral to find one's direction or destiny. One could then spiral outward again and travel the roads of the world without fear of getting lost. It would be possible to create revolutions and build new roads, new possibilities, just like Dad who "[dreams] a road into existence" (501).

In The Famished Road, revolution is neither to be found in any social or political evolution as Azaro's land never becomes independent, nor in the overall diegesis as one of the distinctive features of the novel is repetitiveness. Overall, it appears that only the reader can experience some kind of revolution, thanks to a change in perception. Still, are we to believe that "stories can re-shape the psychic mould of a people, can remould the political and spiritual temper of an age," as Okri claims in Birds of Heaven (1996, 32-33)? Similarly, are we to trust the idea that spiritual change can change the world? After all, despite his evolution, Dad repeatedly fails to revolutionize his surroundings and his community which continues to suffer. Could this hint at Okri's own misgivings or at his fear of failing, like Dad, to communicate his intimate experience to a wider audience?

\section{BIBLIOGRAPHY}

COOPER, Brenda. 1998. "Out of the centre of my forehead, an eye opened: Ben Okri's The Famished Road.” In Magical Realism in West African Fiction: Seeing with a Third Eye, 67-114. London: Routledge.

DEANDRA, Pietro. 1994. “An Interview with Ben Okri.” Africa, America, Asia, Australia 16: 55-82.

FULFORD, Sarah. 2009. "Ben Okri, the Aesthetic, and the Problem with Theory." Comparative Literature Studies 46, no. 2: 233-60.

GANE, Gillian. 2007. "The Forest and the Road in Novels by Chinua Achebe and Ben Okri."

Alternation 14, no. 2: 40-52.

Commonwealth Essays and Studies, 42.1 | 2019 
GLADDING, Rebecca. 2019, 30 Jan. “This is your Brain on Meditation.” Psychology Today. https:// www.psychologytoday.com/us/blog/use-your-mind-change-your-brain/201305/is-your-brainmeditation.

GUIGNERY, Vanessa. 2012. Seeing and Being: Ben Okri's The Famished Road. Paris: CNED.

GUIGNERY, Vanessa, ed. 2013. Imaginary Homelands. Newcastle upon Tyne: Cambridge Scholars Publishing.

GUIGNERY, Vanessa, and Catherine PESSO-MIQUEL. 2013. "Ben Okri in Conversation.” In Guignery 2013, 17-29.

LAMA ZOPA RINPOCHE. 2019, 15 Jan. “The Purpose of Meditation.” Lama Yeshe Wisdom Archive. https://www.lamayeshe.com/article/purpose-meditation.

MAHMUTović, Adnan. 2013. "Revolution Revisited: The Politics of Dreaming in Ben Okri's The Famished Road.” In Guignery 2013, 136-52.

MCCANN, Fiona, ed. 2013, Spring. “Ben Okri." Special issue, Commonwealth Essays and Studies 35, no. 2 .

MONNIER, Fanny. 2018. “Lire The Famished Road, Expérience du Corps.” In Corps en Crise, Crise(s) du Corps, edited by Marine Galiné and Timothy A. Heron, 31-49. Reims: EPURE.

OKRI, Ben. 1991. The Famished Road. London: Vintage, 2003.

OKRI, Ben. 1993. Songs of Enchantment. London: Vintage, 2003.

OKRI, Ben. 1995. Astonishing the Gods. London: Head Zeus, 2014.

OKRI, Ben. 1996. Birds of Heaven. London: Phoenix.

OKRI, Ben. 1998. Infinite Riches. London: Vintage, 2009.

OLIVA, Renato. 1999. "Re-Dreaming the World: Ben Okri's Shamanic Realism." In Coterminous Worlds: Magical Realism and Contemporary Post-Colonial Literature in English, edited by Elsa Linguanti, Francesco Casotti and Carmen Concilio, 171-96. Amsterdam: Rodopi, Cross/Cultures Series. RINGROSE, Christopher. 2013, Spring. “'The Mind Develops Wings': The Famished Road.” In McCann, 78-90.

SYRKIN, Elizabeth. 2013, Spring. "Restoring the Kingdom of the Mind: Trans-realism and Transgressing Aesthetic Boundaries in Ben Okri's Fiction.” In McCann, 45-55.

TANG, Yi-Yuan, Britta K. HÖLZEL and Michael I. POSNER. 2015, March. "The Neuroscience of Mindfulness Meditation.” Nature Reviews Neuroscience. https://www.researchgate.net/ publication/273774412_The_neuroscience_of_mindfulness_meditation.

WALLART, Kerry-Jane. 2013. “Episodes and Passages: Spiralling Structure in Ben Okri’s The Famished Road.” In Guignery 2013, 30-46.

WILKINSON, Jane. 1992. Talking with African Writers: Interviews with Poets, Playwrights and Novelists. London and Portsmouth: James Currey and Heinemann.

\section{ABSTRACTS}

In The Famished Road, Ben Okri presents a country that is on the brink of independence, a transformation that should bring drastic changes but never occurs. Although this public political 
revolution fails, Okri creates a revolution in perceptions for the reader, a revolution, which, rather than going full circle, spirals ever deeper and is anchored in the individual.

INDEX

Keywords: Okri (Ben), repetition, spiral, meditation, transformation

\section{AUTHOR}

\section{FANNY MONNIER}

University Jean Moulin Lyon 3

Fanny Monnier is a PhD student at University Jean Moulin in Lyon. In her thesis on Nigerian writer Ben Okri she analyses how Okri's novels unsettle the reader and the reasons behind such a writerly strategy. Her first published article, "Lire The Famished Road de Ben Okri : expérience du corps," shows how Okri affects his readers through empathic reading. 